\title{
Examination of 10th Grade History Curriculum in Terms of History-Sociology Relation: Case of Turkish high schools 1
}

\author{
Pelin İskender Kılıç* \\ Emine Altunay Şam**
}

\begin{abstract}
This study was centered on the fact that the history course given at high school in Turkey was associated with the topics of sociology based on the interdisciplinary approach in the teaching/learning of the concepts and the subjects in the curriculum. In the study, the document analysis method was used. The curriculum of $10^{\text {th }}$-grade history course was put into practice in the 20172018 academic year, and the concepts and the topics in the content of one of the history coursebooks for $10^{\text {th }}$ graders prepared according to this program in the 2018-2019 academic year with the approval of Board of Education and Discipline of the Ministry of National Education were examined based on the relation between history and sociology. The topics such as "Establishment of the Ottoman State, Meaning Attributed to the State by the Turkish Society, Institutions and Organizations, Economic Activities of the Society, Rebellions, Invasions, Conquests, Transition to Rumelia and Settlement, Turkification and Islamization of the Region, and Migration" in the $10^{\text {th }}$-grade history coursebook are also sociological concepts and phenomena. As a result of this examination, it was determined that sociology would contribute to teaching/learning of the concepts and the topics in the $10^{\text {th }}$ grade history course, considering particularly the learning outcomes in high schools in Turkey.
\end{abstract}

Keywords: History, sociology, historical sociology, history teaching, curricula.

\section{Introduction}

Interdisciplinary studies have principally attracted researchers' systematic and collective attention in such fields as sociology, history, education, administration, and scientometrics (Mäki, 2016, p. 328). The course of history, accordingly, is multidisciplinary in nature. Each of these disciplines contributes to history in different ways. One of the disciplines that history uses is sociology. In many definitions of history, human communities and society are among the elements that do not change. As emphasized in many definitions of history (Togan, 1985, p. 1-2; Kütükoğlu, 1990, p. 2; Kodaman, 1997, p. 1; Özçelik, 2001, p. 17-18; Dilek, 2002; Carr, 2003), history is a discipline which deals with the lives of human communities that lived in the past and the developments that they made in the fields of politics, culture, and civilization. On the other hand, sociology examines the "social reality" (Cangızbay, 2002, p. 68) "emphasizing systematically the contemporary and industrialized systems of human societies" (Giddens, 2000, p. 15). While doing this, it moves from the functions and changes in social institutions (HIz \& Durdu, 2004, p. 31). There is no history without a society; in other words, a person cannot be the subject of history alone. For example, if a volcanic eruption, landslide, flood, or earthquake occurred in the past and people in the indicated places had not, it might have been the subject of geography,

\footnotetext{
1 It is a revised and extended version of the article presented at the International Learning Teaching and Educational Research Congress (6-8 September 2018, Amasya, Turkey).

* Ondokuzmayis University, Samsun, Turkey

** Amasya University, Amasya, Turkey
} 
not history. All kinds of events affecting society in the past, which can be in the political, economic, social or science and art fields, are included in the research field of history.

Humans have to live in society as social beings. All developments in human societies occur throughout history and their results make up today. Therefore, every event that occurs in the historical process and affects the society, and the state established by it takes place in the frameworks of history. For this reason, many thinkers and scientists throughout history looked at history from different perspectives and assigned different missions to it. According to Ibn Khaldun (1332-1406), history is one of the disciplines that nations and tribes had brought through transfer and narration. History tells us how the states and conditions of people and tribes changed, how the state borders expanded, how their strength and power increased, how they constructed the earth until the age of death and destruction came (Ibn Khaldun, 1997, p. 4-5). According to some thinkers, history is defined as the knowledge of today and the past. For example, according to Schilling (1971 as cited in Aksoy, 1998, p. 23), history is not a story; it is humankind's past, and this past is also today's consciousness which is the result of accumulation. Also, Thomson (1983 as cited in Aksoy, 1998, p. 23) states that knowing the past is extremely important for societies. The traditions of today's societies emphasize that their laws and institutions can only be explained by their previous history. Therefore, societies cannot give up history, because the ruins and results of the past always surround society. As a statesman and historian, Meriç (2012) has stated, according to Ahmet Cevdet Pasha (1823-1895), Ottoman sociologist, history is a discipline that must be known by the statesmen who lead politics and, accordingly, the state and the society by their decisions. Since skill in political affairs is created by experience, the life span of a person and the experience of a century is not enough to get every experience. For this reason, smart statesmen do not experience everything themselves; they learn from history. History is an important discipline that should be used for real state affairs, not for the statesman's future and position (Meriç, 2012, p. 67). The Annales School, which appeared in the early $20^{\text {th }}$ century, argues that social history should be emphasized rather than political history. Instead of telling the history of the events, social history introduces an analytical point of view - that the matters leading to it should be emphasized (Yeğen, 2016, p. 26). And for this, inter-disciplinary cooperation in teaching/learning/researching history is necessary. History should especially cooperate with such disciplines as sociology, geography, archaeology, philosophy, anthropology, etc.

Sociology, the subject of which is social events, is, like history, a social discipline. Various events occurred in the historical process and they continue to occur. These events bring about different causes and consequences. Sociology which examines developments, changes, and transformations occurring in the society does not focus on what it should be. It evaluates the society as a whole. It does not assess the society according to individuals. Therefore, the information-gathering methods developed in the discipline of sociology studying the interaction of society and people are not enough to comprehend the historical dimension of social events. A sociologist has to resort to history to better comprehend the events and make more accurate explanations (Sezer, 1993, p. 79), because sociology which examines the structure, causes, and effects of social relations, also examines the social structure, institutions and events arising from the interaction of people and society (Subaşı, 2000, p. 64). This occurs as a result of historical accumulation. Institutions (political, economic, religious, educational, etc.), rebellions, migration movements, production styles and economy, minority issues, constitutional movements, social strata, intellectual movements, etc. are the topics of both history and sociology. The difference between these two disciplines is as follows: while history deals with the information about past events based on documents, by showing place and time, sociology deals with today and tends to generalize events. Therefore, while sociology explains today, it has to look back. Just as a sociologist has to look at the history of an institution or event, thoughts and ideas to make accurate decisions, a historian makes use of sociology in describing social events and institutions and makes connection with today's events or institutions, which will help him to make the subject more concrete. A historian, thus, embodies an abstract historical event in some way. 
Social developments and changes, starting with geographical discoveries but gaining speed with the French Revolution, and the Industrial Revolution, were effective in the emergence of the discipline of sociology. These social movements and the subsequent developments affected the state structures and international relations and prepared the ground for the emergence of new political forces, while some of the old political forces were getting hit, and so, a new era began in class relations (Skocpol, 1979). These were included in the fields of study of sociology and political science at the time, but now they are in the field of study of history. Such developments in societies have brought these two disciplines, which have different approaches, methods, and information-gathering techniques, closer to each other over time. Especially in the $20^{\text {th }}$ century, sub-fields such as social history, historical sociology, and philosophy of history, which were separated by a very thin line in themselves, emerged in parallel with the social developments occurring. In the beginning, sociology was nourished by philosophy in Europe. According to Gurvitch (1950 as cited in Kösemihal, 1954, p. 142-143), sociology in the shadow of the philosophy of history is unacceptable. According to him, sociology initially struggled to solve the problems that the philosophy of history had dealt with for centuries, in other ways. Hence, the philosophy of history is mixed with sociology, which is very dangerous. Also, some historians and sociologists, faced with the challenges of their various knowledge claims from within their disciplines, have turned respectively to sociology and history to reinforce cases that they have felt the resources of their disciplines inadequate to defend (Abrams, 1980, p. 4). However, historical sociology began to be heard frequently since the mid-1970s. Since the mid-1980s, historical sociology has no longer been considered as a sub-discipline of sociology, but as a separate discipline. Thereby, historical sociology, a new discipline, emerged from the inevitable cooperation of the disciplines of history and sociology. Although there were scientists who accepted this discipline as a sub-discipline of history and sociology, the majority believed that it was a new discipline (Skocpol, 1999, p. 402). Historical sociology has been flourishing in both Britain and the United States. However, nearly all the practitioners in Britain have called themselves historians (Calhoun, 2013, p. 615). In the field of historical sociology, Barrington Moore, Reinhard Bendix, Charles Tilly, Immanuel Wallerstein, Peter Anderson, Theda Skocpol, Philip Abrams, and other scientists put forward various opinions. In addition to this, both historians and sociologists issued calls to more and better interdisciplinary relations, and one of them was E.H. Carr's call: ". . the more sociological history becomes and the more historical sociology be- comes, the better for both. Let the frontier between them be kept open for two-way traffic." (Calhoun, 2013, p. 616)

In Turkey sociology has been fed by history. When it has been viewed in Turkey's historical tradition, it has seemed that history was the forerunner of social sciences (Meriç, 2012, p. 70-71). For example, according to Mills (1959, p. 143), without the use of history and a historical sense of psychological matters, a social scientist cannot adequately state the kinds of problems that ought now to be the orienting points of his studies. Many radical innovations had been made in the fields of bureaucracy, army, education, and in the social field, especially since the reign of Mahmut II (1785-1839) in the Ottoman State. These innovations starting from the beginning of the $19^{\text {th }}$ century had shown their effectiveness in the second half of the century and more comprehensive innovations had continued in all these areas. These Westernization movements had some reflection in the social field. As a result of all these, sociology was known and followed by the Ottoman intellectuals in the 1890s. The reason for this was mostly related to the Constitutional Period and the conditions of the period. The political leg of the political and social crisis in the country during the Constitutional Period was somewhat resolved with the "Declaration of Freedom". However, it could not take place in the social field. The social order had to be reorganized based on all these developments, but there was no sign of that. Therefore, sociology for the Ottoman intellectual had been seen as a discipline to teach the ways of "how to westernize, how to achieve economic development and how to move to modern society", in other words, to present "recipes of salvation" to the state and social powers (Bulut, 2011, p. 4). The intellectuals of the period who took action to resolve the social leg of the socialpolitical crisis, began to look for the remedy in the example of France having similar problems again in the West. Seeking for political-social institutionalization required at the point of scientific analysis of social facts, and capitalist social relations were the 
most serious search for France after the revolution. When French sociologists considered themselves responsible for these political-social institutionalization efforts, Turkish society and state experienced the pain of the transition from empire to the nation-state (Arslanoğlu, 2012, p. 33). As a result of this, sociology courses have been included in Istanbul University curriculum since 1914. In particular, Prince Sabahattin (1878-1948) and Ziya Gökalp (1876-1924) were the leading figures in the conditions of that day (Gökçe, 2000, p. 74-75). Since the 1915-1916 academic year, sociology course has been taught at the Faculty of Literature, and İçtimaiyat Mecmuası (Journal of Sociology) was published in 1917 (Bulut, 2011, p. 8).

For the first time, the studies to establish the National Education system were started at the Education Congress held in 1921 in Turkey. The second curriculum was prepared in 1922. Immediately after the proclamation of the Republic, the Law of Unification of Education (Tevhid-i Tedrisat Kanunu) was adopted on March 3, 1924. All educational institutions were subordinated to the Ministry of National Education. Then, important changes were made in the curricula. In the curriculum of 1924 which was the first high school program, the focus was on the history course. The course of Turkish Civilization History was added to the literature branch, and 2 hours of sociology were delivered to both the science and literature students (Cicioğlu, 1985, p. 197). The reason for adding the sociology course to the high school program in 1924 was stated in the Secondary Education ${ }^{2}$ Curriculum as follows: "It has been deemed necessary for students to think over social problems, to know the effects of society on the individual and to get an idea about evolution." (Arslanoğlu, 2001, p.66). Sociology studies were carried out within the body of the Turkish Philosophical Society established in 1928 (Bulut, 2011, p. 9). In the following years, the sociology course was sometimes included under the name of philosophy and was also sometimes included in the curricula as a tripartite group under the name of philosophy, logic, and sociology (Ünal \& Ünal, 2010, p. 115).

Teaching sociology has been offered at the college level since at least 1876 in the United States. The this discipline, however, has been part of high school social studies curricula since the dates of 1911-12 school year (DeCesare, 2005, p. 235).

\section{Conceptual Framework}

It can be seen from the above explanations that the conceptual framework of this study includes history, sociology which is one of the disciplines used by history, historical sociology, history teaching, history curriculum, and interdisciplinary approach. Many definitions were offered related to history, historical sociology, history teaching and sociology. Various hypotheses, theories, and methods were developed. However, there were insufficient scientific studies on what should be the contribution of sociology in history teaching. There were some recent studies, e.g. Dündar's (2019) thesis. The most recent studies have been held rather in the field of sociology of history (historical sociology). In addition to them, there have been some studies about the place and importance of sociology in the studies of history, even though they were limited in number. These were written by scientists working in the fields close to history such as social classes, capitalism, globalization and migration, underdevelopment, imperialism, technology, and social change in sociology in general (Erbaş, 2017, p. 223-256). Also, some institutions or events in different countries or cities were analyzed using the comparative history method (Yalansız, 2009, p. 493- 498) and the importance of historical topics in sociology course was discussed (Akran, 2019).

With the advancement of science, many disciplines were separated and divided into completely different fields. This concerns not only natural, but also social sciences. This attention to very fine details brought about rapid advances in science. However, after a while, still other disciplines were needed to be able to explain some of the developments which occurred within

\footnotetext{
${ }^{2}$ Secondary education is often referred as high school education, since the schools are called lyceum.
} 
these disciplines. This also inevitably brought with it an interdisciplinary approach. For example, if a historian wants to put the causes of a social uprising within the state on a solid ground, he has to look at both the social structure of the state, the geography in which it is located, its effects, and also its cultural accumulation and many other factors. This also inevitably requires effective interdisciplinary cooperation, because one scientist cannot grasp every aspect of the studied phenomenon. Knowing everything means not knowing anything (Erbaş, 2017, p. 226-227), or knowing a little bit of everything is an obstacle to scientific development. Therefore, interdisciplinary cooperation is important, and historical science also cooperates with various sciences according to the topics which it examines. Sociology is one of the disciplines.

\section{Method}

The general aim of this study is to determine to what extent sociology, one of the disciplines used by history, can contribute to the teaching/learning of the concepts and the topics of history concerning an interdisciplinary approach. Thus, the subject of the study was handled in line with two sub-problems. The first one is "Where do the history and sociology disciplines intersect in the context of the subjects in the $10^{\text {th }}$-grade history curriculum?" and the second one is "How can sociology be used to explain and understand the behaviours in societies in the historical process?" As a result of the literature review, the focus was on how the coordinated teaching of these two sciences in high school in terms of curriculum, grade levels and lesson hours could be effective in teaching/learning the concepts and topics in the 10th-grade history lesson, because these two disciplines contribute a lot to each other and intersect in a separate field of study such as "historical sociology".

In this study, research data were collected through document review, which is one of qualitative research methods. Document review involves analysis of written materials which contain information about the phenomenon or phenomena intended to be investigated (Yıldırım \& Şimşek, 2005, p. 187-188). It was focused on the importance of knowing the concepts, the terms, and the phenomena related to sociology in these topics in teaching/learning of history topics. Accordingly, the $10^{\text {th }}$-grade history curriculum implemented by the Ministry of National Education (MEB) as a consequence of the renewal studies carried out in the 2017-2018 academic year and the unitized annual plan prepared as a result of this program were taken as a basis. Besides, the units of a history coursebook (Yüksel, et al., 2019) among the history coursebooks deemed appropriate to be taught in the $10^{\text {th }}$ grades of secondary education institutions by Board of Education (TTKB) were examined in this direction ${ }^{3}$. Similarly, the sociology curriculum implemented in consequence of the renovation studies carried out in the 2008-2009 academic year and the unitized annual plan prepared as a result of this program were taken as a basis. Also, the units of a sociology coursebook (Ekici, 2017) among the sociology coursebooks deemed appropriate to be taught in the secondary education institutions by the Board of Education were examined in this direction.

\section{Results}

The units, the number of their learning outcomes, the approximate time that could be allocated for the processing of learning outcomes, and their ratio to the class hours in the sociology curriculum are given in Table 1 (MEB, Secondary Education Sociology Course Sociology Curriculum, 2009).

\footnotetext{
${ }^{3}$ References in the form of "history coursebook" in the text are to the history course book examined.
} 
Table 1. The units, the number of their learning outcomes, the approximate time that could be allocated for the processing of learning outcomes, and their ratio to the class hours in the sociology curriculum

\begin{tabular}{lccc}
\hline Unite & $\begin{array}{c}\text { The number of } \\
\text { learning } \\
\text { outcomes }\end{array}$ & Class Hours & Ratio (\%) \\
\hline Introduction to Sociology & 5 & 6 & 8 \\
Individual and Society & 10 & 10 & 14 \\
Social Structure & 5 & 7 & 10 \\
Social Change and Development & 10 & 12 & 17 \\
Society and Culture & 8 & 12 & 17 \\
Social Institutions & 22 & 25 & 34 \\
TOTAL & $\mathbf{6 0}$ & $\mathbf{7 2}$ & $\mathbf{1 0 0}$ \\
\hline
\end{tabular}

Unit 1 is Introduction to Sociology. The time allocated to this unit is 3 weeks, namely 6 lessons. The number of learning outcomes is 5 , and its ratio to the class hours is 8 . In this unit, such topics as "What is sociology? What are the elements which make up society? How was sociology as a science introduced? What are the methods and techniques of sociology? How is sociology discussed in Turkey?" are taught. In the concepts section of the unit, there are sociology, society, social event, social phenomenon, social groups, and research techniques. The unit also includes concepts and terms in the topics of history course such as institution, establishment, state, power, forms of political government, French Revolution, Industrial Revolution, Geographical Discoveries, Renaissance, Reform, Age of Enlightenment, Colonialism, Constitutionalism, Young Turks, decentralization.

Unit 2 is Individual and Society. The time allocated to this unit is 5 weeks, namely 10 lessons. The number of learning outcomes is 10 , and its ratio to the class hours is 14 . In this unit, such topics as socialization and elements of socialization, stages of socialization, and social relations, social status, social role and respectability, social values, social norm and control, social deviation, rights and duties, privileges and responsibilities are taught. In the concept section of the unit, there are socialization, respectability, social control, social status, social role, social values, social norm, and social deviation. The unit includes also concepts and terms in the topics of history course such as sociocultural, written rules, unwritten rules, law, tradition, race, dominance, population, and duty.

Unit 3 is a Social Structure. The time allocated to this unit is 4 weeks, namely 7 lessons. The number of learning outcomes is 5 , and its ratio to the class hours is 10 . In this unit, such topics as social structures and elements, types of social interaction, social stratification and stratification in Turkey, and social mobility are taught. In the concept section of the unit, there are social structure, social stratification, social interaction, social mobility, social structure, social interaction, social stratum, vertical mobility, institutional structure, and horizontal mobility. The unit also includes concepts and terms in the topics of history course such as law, immigration, population exchange, nation, nationalism, populism, oppression, prisoner, punishment, power, feudality, social strata, class, military, caste, slave, noble, senor, serf, artisan, Ottoman Empire, Sultan (padişah), rulers (soldiers), people (reaya), seyfiye (army members), ilmiye (ulema class), kalemiye (bureaucrats), palace employees, peasants, townspeople, tradesmen, tax, and production.

Unit 4 is Social Change and Development. The time allocated to this unit is 6 weeks, namely 12 lessons. The number of learning outcomes is 10, and its ratio to the class hours is 17 . In this unit, such topics as the phenomenon of social change and the factors affecting social change, science, technology and mass media, modernization and globalization, social development and its elements, social integration, social disintegration, and its causes are taught. In the concept section of the unit, there are social change, media, modernization, globalization, social development, and social disintegration. The unit includes also concepts 
and terms in the topics of history course such as complete independence, secularism, neighbourhood, culinary and nutritional culture, classical period, uprising, empire, nation-state, and plunder.

Unit 5 is Society and Culture. The time allocated to this unit is 6 weeks, namely 12 lessons. The number of learning outcomes is 8 , and the ratio to the class hours is 17 . In this unit, such topics as the meaning of the concept of culture, the elements of culture, the functions of culture and its contribution to social integration, cultural processes, cultural attitudes and intercultural interaction are taught. In the concepts section of the unit, there are culture, popular culture, traditions and customs, cultural attitude, cultural process, cultural imperialism, cultural relativity, cultural centrism, acculturation, culture shock, cultural degeneration, and subculture. The unit includes also concepts and terms in the topics of history course such as culture, material culture, spiritual culture, moral laws, civilization, art, epic, dictatorship, ethnic, and imperialism.

Unit 6 is Social Institutions. The time allocated to this unit is 12 weeks, namely 25 lessons. The number of learning outcomes is 22 , and its ratio to the class hours is 34 . In this unit, such topics as social institutions and their functions, family institution, marriage, divorce and family continuity, family models, the place and importance of women in society, education and social life, religion, secularism and Atatürk, economy and social life, components of the economy, and economic systems, political institution and basic concepts of politics, forms of political government, and democracy are taught. In the concept section of the unit, there are institutions, marriage, family, nuclear family, extended family, divorce, democracy, production-consumption, women's rights, education, religion, secularism, economy, capitalism, socialism, and politics. The unit includes also concepts and terms in the topics of history course such as institution, state, democracy, theocracy, monarchy, aristocracy, oligarchy, productionconsumption, education, religion, secularism, constitution, economy, politics, Göktürks, Uyghurs, and European Huns.

Table 2. The frequency of the words in the sociology coursebook and the topics of the history course

\begin{tabular}{lc}
\hline Words & Number \\
\hline Society/Social & 1.375 \\
Culture & 706 \\
Family & 308 \\
Religion, Economy, Education & $201-250$ \\
State, System, Strata/Stratification & $151-200$ \\
Science / Scientific, Political / Politics, Class, People & $101-150$ \\
Government, Law, Nation, Tradition & $51-100$ \\
Power, Authority, Justice/Injustice, Oppression, Islam, War, Law (Code), Migration, Population, Penalty & $15-50$ \\
\hline
\end{tabular}

The units, the number of their learning outcomes, the approximate time that could be allocated for the processing of learning outcomes, and their ratio to the class hours in the $10^{\text {th }}$-grade history course curriculum are given in Table 1 (MEB, Secondary Education History Course Curriculum, 2018).

Table 3. The units, the number of their learning outcomes, the approximate time that could be allocated for the processing of learning outcomes, and their ratio to the class hours in the $10^{\text {th }}$ Grade History Course Curriculum

\begin{tabular}{|c|c|c|c|}
\hline Unit & $\begin{array}{c}\text { The number of } \\
\text { learning } \\
\text { outcomes }\end{array}$ & Class Hours & Ratio (\%) \\
\hline Seljuk Turkey in the Process of Settlement and State Formation & 6 & 12 & 16,6 \\
\hline Ottoman Politics from Beylic to the State (1302-1453) & 6 & 14 & 19,4 \\
\hline Warriors and Soldiers in the Process of State Formation & 3 & 8 & 11,1 \\
\hline Ottoman Civilization from Beylic to the State & 4 & 10 & 13,8 \\
\hline World Power Ottoman (1453-1595) & 7 & 20 & 27,9 \\
\hline
\end{tabular}




\begin{tabular}{|c|c|c|c|}
\hline Sultan and Ottoman Central Organization & 2 & 2 & 2,8 \\
\hline Ottoman Social Order in the Classical Age & 5 & 6 & 8,4 \\
\hline TOTAL & 33 & 72 & 10 \\
\hline
\end{tabular}

Unit 1 is Seljuk Turkey in the Process of Settlement and State Formation. The time allocated to this unit is 6 weeks, namely 12 lessons. The number of learning outcomes is 6 , and its ratio to the class hours is 16.6. In this unit, such topics as Oghuz Turks' immigration to Anatolia, the Turkification of Anatolia, the process of state formation of Turks in Anatolia, the first Turkish political organizations and activities in Anatolia, the struggles with the Crusaders, the political, social and cultural change caused by the Mongolian Invasion in Anatolia" are taught. In the concept section of the unit, there are tribe troops, Turkish beylics, Crusaders, Battle of Myriokephalon, Battle of Kösedağ, Mongolian invasion, Oghuz Turks, and Babai Revolt. The unit includes concepts and terms in both history and sociology such as uprising, tribe, state/state formation, immigration/migrant, nomad, crusader, people, nation, invasion, conqueror/conquest, war (battle), holy war/ghazi, jihad, Turkification, Islamization, sect, religion/divine religion, cult, Sufism, Sufi, oppression, political organization, culture/ cultural change/cultural interaction, sociocultural/socioeconomic, and buffer state.

Unit 2 is Ottoman Politics from Beylic to the State (1302-1453). The time allocated to this unit is 7 weeks, namely 14 lessons. The number of learning outcomes is 6 , and its ratio to the class hours is 19.4. In this unit, such topics as the reasons of the multicultural structure of Anatolia, social life, the geopolitical situation of Anatolia, the origin of the Ottomans and the opinions put forward about it, the impact of the military, social and economic groups in the reasons of the expansion of the Ottoman Empire, conquests and settlement and tolerance policies ${ }^{4}$ in Rumelia, ensuring the transition of nomadic Turkmens to settled life, Ottoman interregnum, and attempts aimed at ensuring Turkish political unity in Anatolia are taught. In the concept section of the unit, there are Bithynia, settlement, tolerance, holy war, Ottoman interregnum, Ahiyân-ı Rûm, Bâciyân-ı Rûm, and the Sheikh Bedreddin' revolt. In unit 2, the concepts related to sociology, which differ from unit 1, are multiculturalism, Ottoman interregnum, non-Muslim, settlement, identity, Greek, and exile.

Unit 3 is Warriors and Soldiers in the Process of State Formation. The time allocated to this unit is 4 weeks, namely 8 lessons. The number of learning outcomes is 3 , and its ratio to the class hours is 11.1. In this unit, such topics as the military power of the Ottoman Empire during the beylics and the elements that created this power, collecting ${ }^{5}$ system and the janissary quarry, timar system ${ }^{6}$ and the political, and social and economic features of this system are taught. In the concept section of the unit, there are $a^{7} p^{7}$ ghazi, people, warrior, the janissary quarry, collecting system, timar system, and timarli sipahis ${ }^{8}$. In unit 3 , the concepts related to sociology, which differ from the units 1 and 2, are system, army, organization, and tax.

Unit 4 is the Ottoman Civilization from Beylic to the State. The time allocated to this unit is 5 weeks, namely 10 lessons. The number of learning outcomes is 4 , and its ratio to the class hours is 13.8 . In this unit, such topics as the effects of the teachings of Sufis and scholars on Islamization of Anatolia, the structure of the Ottoman state administration based on the combination of ilmiye $^{9}$, kalemiye $^{10}$, and seyfiye ${ }^{11}$ classes, the effects of oral and written culture on social life in Ottoman geography, craft, art, and

\footnotetext{
${ }^{4}$ Tolerance is "istilamet" in Turkish, and istilamet is the name given to a policy carried out in the Ottoman State. Tolerance policy is the general name of the policies attempted to keep the non-Muslim population in the newly conquered places connected to the state.

${ }^{5}$ It is "Devshirme" system in Turkish. It is the system of gathering young and talented Christian children from the lands conquered by the Ottoman Empire, especially the Balkans, and making them become a superior soldier or bureaucrat through a hard education.

${ }^{6}$ It is the allocation of land as a fee for a defined service provided to the state in its most general context.

${ }^{7}$ It means "brave, valiant" in Turkish, and was used as a kind of title.

${ }^{8}$ Spahi is the name of heavy cavalry soldier in the Ottoman army. Timarli spahi's main duty was to participate in war in time of war, to ensure the security of the region in peacetime, to collect taxes from the people within his timar according to the timar system, and to both support himself and also train soldiers with these taxes according to the size of his timar.

${ }^{9}$ Ulema class.

${ }^{10}$ Bureaucrats.

${ }^{11}$ It is the term used for the members of the administrative and military class called "ehl-i örf" in the Ottoman State
} 
cultural activities in the Ottoman geography and changes in social life depending on them are taught. In the concept section of the unit, there are ilmiye class, Sufism, kazasker ${ }^{12}$, madrasah, calligraphy, ulema, kalemiye class, kadı ${ }^{13}$, craft, seyfiye class. In unit 4, the concepts related to sociology, which differ from the first three units, are ilmiye class, Islam/Islamization, culture/cultural change, kalemiye class, and seyfiye class.

Unit 5 is a World Power Ottoman (1453-1595). The time allocated to this unit is 10 weeks, namely 20 lessons. The number of learning outcomes is 7 , and its ratio to the class hours is 27.9 . In this unit, such topics as political developments between the dates of 1453-1520; the conquest of Istanbul, its causes and consequences; the effects of the Ottoman State's dominance in the Islamic geography on the Turkish and Islamic world; political developments between the dates of 1520-1595; political borders of the Ottoman State and the state organization since the period of Suleiman the Magnificent; the strategic competitors of the Ottoman State; and the policies of the Ottoman Empire in the land and sea are taught. In the concept section of the unit, there are conqueror, feth-i mübin ${ }^{14}$, Yavuz, Magnificent, capitulation, concession, Battle of Preveza, geographical discoveries, Hilafet-i Ulya ${ }^{15}$, Protestant. In unit 5, the concepts related to sociology, which differ from the first four units, are economy, conqueror/conquest, power, and strategy.

Unit 6 is a Sultan and Ottoman central organization. The time allocated to this unit is 1 week, namely 2 lessons. The number of learning outcomes is 2, and its ratio to the class hours is 2.8. In this unit, such topics as the role of Topkapı Palace in the state administration, in the training of statesmen and the development of city culture; the Sultan, the Ottoman Dynasty and the Ottoman Law are taught. In the concept section of the unit, there are birun ${ }^{16}$, enderun ${ }^{17}$, kazasker, confiscation system in the Ottoman State, dynasty, code of laws, and the book of government. In unit 6 , the concepts related to sociology, which differ from the first five units, are justice, education, governance (government), and law.

Unit 7 is Ottoman Social Order in the Classical Age. The time allocated to this unit is 3 weeks, namely 6 lessons. The number of learning outcomes is 5 , and its ratio to the class hours is 8.4. In this unit, such topics as the structure of the Ottoman society, and the national system, the effect of Islamic culture in the places conquered by the Ottoman State, the soil system in the Ottoman State, the place of the guild organization in the Ottoman economic system and the social structure, and the place of the foundation institution in the social life in the Ottoman State are taught. In the concept section of the unit, there are nation system, sect, foundation, guild, çifthane ${ }^{18}$, narh ${ }^{19}$, religious community, and miri ${ }^{20}$. In unit 7, the concepts related to sociology, which differ from the first six units, are religion, law, organization, and society. The frequency of the words in the entire $10^{\text {th }}$-grade coursebook and sociology is given in Table 4.

Table 4. The frequency of the words in the $10^{\text {th }}$-grade history coursebook and sociology

\begin{tabular}{ll} 
Words & Number \\
\hline State & 893 \\
War/Battle, conqueror/conquest & $201-250$ \\
Islam, political/politics, crusader, army & $151-200$ \\
\hline
\end{tabular}

\footnotetext{
${ }^{12}$ He was a military judge, a high official in the Ottoman judiciary.

13 Muslim judge.

${ }^{14}$ Clear and bright victory. This victory can be either with or without war. It is included in the first verse of the surah of conquest.

${ }^{15} \mathrm{It}$ is the supreme authority in which the Islamic world is represented, and its representative is called the caliph.

${ }^{16}$ It is the section outside the harem department and the inner department of the palace in the Ottoman palace.

${ }^{17}$ It is the inner department of the palace.

${ }^{18}$ It is a system in which the labour of the family, a couple of oxen and the cultivated land created a production unit and hence, a financial unit. The household, the producer, was taken as the basis for taxation.

${ }^{19}$ Officially fixed price.

${ }^{20}$ Belonging to the government or state treasury.
} 
System, culture, people, law, ghazi/holy war 101-150

Education, religion, power, organization, society/social, class, economy, nation, authority, Turkmen 51-100

Rebellion/Uprising/Rebel, Government, Science/Scientific, Family, Migration, Law, Justice/Injustice,

Prisoner, Peasant, population, oppression, Turkization, tradition, institution, sect, penalty, class

$15-50$

\section{Discussion and Conclusion}

Historical and social facts cannot be directly observed, and no social phenomenon can be analyzed abstractly by detaching it from its social content. Therefore, evaluating historical facts through sociological materials will make it more concrete (Aksoy, 2000, p. 24-25). Likewise, if a sociologist is disconnected from history and does not approach the issues of society from a historical perspective, he / she cannot properly justify matters that will guide today's research (Ergun, 1973, p. 11). As stated by C. Wright Mills in his book "The Sociological Imagination", "every social science - or better yet, every well-thought social study- requires a wide range of historical insights and full use of historical material" (Skocpol, 1999, p. 1). Then, a researcher who examines the Turkish social structure and institutions must firstly consider the historical development of Turkish society (Aksoy, 2000, p. 24). Therefore, the closeness of history and sociology to each other cannot be ignored. Further, due to this feature, it is sometimes seen that they even take over the role of each other. So, it has reached the level that "sociology is the history of today, and also history in the sociology of the past", and with this level exceeded, in the words of Braudel, it has reached the point that "history and sociology are not the fronts or rear side of the same fabric, but it is the full thickness of the threads of this fabric" (Braudel, 1992 as cited in Fildiş, 2015, p. 792).

Unit 1 is Seljuk Turkey in the Process of Settlement and State Formation. In this unit, the migrations of the Oghuz tribe to Anatolia and the subsequent developments are mentioned. "Tribe" was an important organization in Turks. It was the smallest political unit and there was a state of belonging to the tribe. The tribe had a leader and everyone must obey the decisions made in the tribe. Those who did not obey them would face various sanctions. The state was formed when the tribes came together. State understanding in Central Asia and the mission imposed on the state (Ögel, 2016) continued also when those settled in Anatolia. Looking at the Turkish history, it was seen that Turks quickly established the state and army organization. In general, in Turks, the state was founded by members of the army, or the head of the state was also at the head of the army. Looking at Turkish history, there was almost no period when Turks lived without a state. When a Turkish state collapsed, another was established instead, or the people joined the other existing Turkish state. Therefore, Turks living under the sovereignty of various states were generally assimilated in the long term as a result of various reasons. Hence, living in a state union established by them was a reason for the existence of the Turkish people. Thus, even after coming to Anatolia and deciding to settle here, they made political organization firstly as the beylics and then as a state. The arrival of Kayı tribe, one of the Oghuz tribes, to Anatolia is an immigration event. There are two views on this subject. One group, having the greater majority, says that Kayı tribe came to Anatolia with the Battle of Manzikert (1071), and the other group, having minority, states that they fled from the Mongol invasion and came to Anatolia (Kürkçüoğlu, 2013). The semi-nomadic Oghuz tribes, namely Turkmen, had started to make raids in Anatolia since the beginning of the 11th century to explore and gain loot. The raid was not a war. Rather it was made for exploratory purposes and loot. However, they had made raids to regard Anatolia as their homeland since the Battle of Manzikert (1071). The beginning of Turkification and Islamization of Anatolia had caused the Crusades, which started in 1096 and continued until 1291 , against the Turkish-Islamic world. As a result of the Crusades, the interaction of Eastern and Western cultures which were two very different cultures brought some developments in almost every field. 
Another important event of this period was the political and social change caused by the Mongolian invasion in Anatolia. Before this invasion, the Oghuz Turks had some economic and social discontent with the state. As a result, the Babaî revolt of 1240 broke out. This revolt mostly revealed social, economic, and political problems in Anatolia. If a country was in turmoil, it would not be expected to be successful abroad. The Mongolians, the powerful state of that time who took advantage of this opportunity, mobilized towards Anatolia. With the defeat that occurred as a result of the Battle of Kösedağ (1243), Anatolia was invaded by the Mongols. The Turks struggled to exist in Anatolia during this period. The Anatolian Seljuk State received a major blow, and the central state gave place to the beylics which were established in the form of small or large, and so, the second period of the beylics began. This situation had important political and sociocultural results.

Sociology which is interested in today and tends to generalize events looks back and reveals the value and importance attached by the Turkish nation to the state in the face of various events today. The establishment of the state organization later by the Ottoman State being a beylic and the institutions of this state are in the field of study of sociology. Likewise, the migration event and the problems and consequences that it brings are also one of the fields of study of sociology. There are such questions as "What is the state sociologically? What is Turkification? What are immigration and migrants? What is semi-nomadic or nomad? What are the reasons that force societies to migrate? What is a revolt and what are its consequences in terms of society? What is the invasion? What are its consequences? What does the sociocultural structure mean?" Knowing these concepts and their effects sociologically will make an important contribution in terms of learning and understanding of the subject.

Unit 2 is Ottoman Politics from Beylic to the State (1302-1453). In this period which was the establishment phase of the Ottoman State, the first Ottoman conquests and wars, namely political developments, and social and cultural structures causing them or affected by them are mentioned. In this period, Anatolia and the Balkans were in political turmoil. Especially in the Balkans, there were small and large kingdoms and beylics. While Serbian, Bulgarian, and Hungarians were kingdoms, and effective powers, Albania, Bosnia, Herzegovina, Wallachia, Moldavia, and Ardeal were the beylics. There was a struggle for domination among them. There was no political union in the region, nor was there a religious union. Religion and sectarian conflicts, which were a highly effective institution as a feature of the period, brought with it also social confusion and conflicts among societies. The Ottoman State, which wanted to take advantage of this environment where there were political and religious conflicts, started to move towards the Balkans. It implemented a settlement policy to provide a more permanent settlement in this region. The settlement is the name given to moving the settled or nomadic groups to another region for reasons such as Turkification, Islamization, enlivenment, or providing security of a certain region at the request of themselves or the state (Şimşirgil, 2013, p. 3). As it could be understood from the definition of this settlement movement, it occurred for various reasons. There was also settlement through exile (Ünlü, 2010, p. 306). Turkification and Islamization of this region were not only through transferring the population. Along with the population, this was supported also by cultural and economic activities. For example, a great reconstruction activity was observed by building bridges, fountains, libraries, public soup kitchens, mosques, and madrasahs in the settlements. Accordingly, settlement activity in the Ottoman State made cities look like Turkish-Islamic cities with cultural monuments, and this was supported by treating the people fairly and taking fair taxes from them. In other words, tolerance (bringing the people closer to itself by treating the conquered region fairly and winning their hearts) policies were also followed (Ünal, 2011, p. 355). Another important issue of this unit is the Battle of Ankara (1402) between the Ottoman State and the Timur State, the two Turkish states. In this war, the two Turkish states fought for leadership. As a result of this war, the Ottoman State being a political power had come to the level of disintegration, Turkish unity had been broken in Anatolia, the beylics had been re-established, and an environment of chaos that would last 11 years had been created. In addition to these uncertainties, the lack of political unity had led to some economic, social, and religious problems over time, and this had also caused the Sheikh Bedreddin revolt. 
To make these issues more concrete while explaining them, the students can be provided to learn more permanently by giving examples of religious, sect or political events occurring from time to time in Balkan societies today, because these events can occur from time to time as an extension of the problems in history. For example, the events of Bosnia and Herzegovina having both religious and sectarian and also political aspects which have occurred in the recent past, and the relations with Serbs can be made more concrete with photographs and documentaries. Today, the struggle areas in history continue more or less. Bulgarian, Hungarian, and Serbs are more influential forces in the region within the Balkan states. Serbs continue their activities, whenever they find opportunities, on Bosnia, Herzegovina, Montenegro, and Kosovo to reach the Adriatic. Therefore, all kinds of political, social, and religious struggles of these societies from history are somehow continuing also today under the requirements of the age. For this reason, when a sociologist is researching his field in this area, he should refer to history to understand the historical process and the structures of the societies existing in this process, because, for a sociologist, religion and the state are two important institutions affecting societies. History teachers who lecture on this topic can also use sociology to make the subject more concrete and can provide more effective learning by giving examples from today. They can refer to today's extensions and reflections of these events. They can open the effects of raids and settlements and get and losing the land on the states and the societies up for discussion. Similarly, the reasons causing resettlement, the classes subject to settlement, and their results are sociological events that continue their effects and cause some problems. Today, the effects and traces are still visible even if these regions are not under the control of the Turks. By organizing a trip to this region, it may be possible to see the traces of Turkish and Islam both in historical and cultural artifacts and also in the lives and traditions of the people.

So there are such questions as "What did the effects of the geopolitical situation and characteristics of Anatolia and the Balkans have on politics and sociocultural structure? What are the dynamics of reconciliation-conflict? What are the effects of religion and sectarian conflicts on the societies? What are settlement and tolerance? What were their sociocultural effects in the region? What is exile? What is the purpose of exile? What are the similarities between the Babaî revolt in the previous unit and the Sheikh Bedreddin revolt in this unit? If a state's political authority was shaken, if there were imbalances in social and economic life, and religious societies became a distinctive factor, what effects would this have on the state, nation, and society?" Explaining and supporting their answers sociologically is extremely important in terms of understanding the topics.

Unit 3 is Warriors and Soldiers in the Process of State Formation. In this unit, warrior communities, concepts such as alp and ghazi also indicating social status, military organization and groups making up this organization, political and economic dimensions of distinction between the soldiers and the people in Ottoman social order, political, social and economic features of timar system, and the janissary quarry and collecting system are mentioned. In the unit, tribal warriors, mercenaries, and various military forces having different features and structures such as those fighting for faith and religion are explained. Each of these forces undertook different missions within the state. In the Ottoman social order, the distinction between soldiers and people was important, because the military groups would not pay taxes to the state in exchange for service. Those living in the city, town, and village, and nomads were called the people and they would pay taxes. Timarli sipahis and Kapıkulu ${ }^{21}$ army were two effective forces in the Ottoman army system, and they were an element of balance against each other. Timarli sipahis were generally composed of Turks and they were soldiers scattered throughout the country. They would inhabit in the countryside, would ensure the security of the area they were assigned, would collect taxes, would check whether the soil was planted or not, and would raise the soldiers in an amount whose conditions were determined by law. Hence, they were intertwined with society, and the slightest glitch or unlawfulness that could occur would cause social problems. Kapıkulu soldiers were the ones who protected the Sultan and the capital Istanbul (Uzunçarşıll, 1988). The soldiers taken to this quarry were largely chosen from the collecting system until

\footnotetext{
${ }^{21}$ It was the collective name for the household troops of the Ottoman Sultans.
} 
janissary law broke down and the disruption began in the quarry at the end of the $16^{\text {th }}$ century. The collecting system was very effective during the state formation of the Ottoman, because the children chosen in this way had reached important positions many of the grand viziers were from the collecting system- in many institutions of the state according to their abilities and achievements.

In this unit, the disruption of the public and military groups is extremely important in terms of social stratification. What social stratification is, and its role in society is the subject of sociology. It is important to comprehend this to better understand the topic. Similarly, questions such as "What is social status? What is an organization? Why is it needed? What is the importance of the tax system for the state and society?" are the ones that examine the concepts and the phenomena related to this topic. The questions such as "What is the collecting system? What is its place in the state organization?" have caused many scientific researchers and, accordingly, differences of opinion by both Turkish and European historians. These are included in the coursebook with their examples (Yüksel et al., 2019, p. 85-94). The collecting system that was effective in ensuring the state authority is also a sociological concept, because a new class was created due to it. This class had also an important place in the Ottoman state and military organization, and, therefore, it is a sociological issue whose effects on social life should also be examined. As for the timar system, the answers to the questions such as "What does it mean in terms of sociology? Evaluate it from the military, social and economic perspectives. Compare the collecting system with feudalism. What is the place of this system in social life?" are important to ensure more permanent learning.

Unit 4 is the Ottoman Civilization from Beylic to the State. This unit is about the Islamization of Anatolia. In this process, dervishes, Sufis, scholars, and ghazis played an important role. In the words of Ömer Lütfü Barkan (1902-1979), colonizer Turkish dervishes carried out a systematic migration and settlement activity in Anatolia (Barkan, 1942). This situation significantly affected the sociocultural structure of Anatolia. In this unit, ilmiye, kalemiye, and seyfiye classes who were ruling class in the Ottoman state organization are emphasized, and their effects on the society are mentioned. Their duties and powers were determined by legislations. Especially ilmiye class undertook important duties in science, education, law, and some state affairs. Kalemiye class constituting the Ottoman bureaucracy was effective in the emergence of official correspondence procedures. In seyfiye class, there were kapıkulu soldiers and timarlı sipahis, and also officers such as subaşı ${ }^{22}$, sanjak-bey, beylerbeyi ${ }^{23}$, viziers, and grand vizier. In addition to the central organization, the provincial organization was also important, especially because it was in a oneto-one relationship with the public. Most of the officers here were appointed by the center. Apart from this organization, the effect of the oral and written culture of the Ottoman State on social life is discussed in the unit. Craft, art, and cultural activities are mentioned. The transformation in the structure of cities in Anatolia and Rumelia, urban planning, architecture, woodworking and stonemasonry, and people acquiring them as a profession with their importance in city life are explained. These professional groups established craft guild, depending on the organization of the Turkish-Islamic guild ${ }^{24}$. These also had some rules. The organization of the Turkish-Islamic guild had political, social, educational, and religious dimensions, especially economic ones. Therefore, it had an important place in the Ottoman social structure.

The answers to the questions such as "What is Islamization sociologically? What is the Bureaucracy? What is the provincial agency? What is urban culture? What is the organization of the Turkish-Islamic guild? What are their reflections and examples today? As stated in the book, what can be said when the Ottoman cities are compared with today's cities?" can make an important contribution in terms of learning and understanding the topic.

\footnotetext{
$22 \mathrm{He}$ was the one dealing with security affairs in wartime and being charged with collecting taxes also in peacetime by selecting from among kapıkulu cavalries during the Ottoman period.

${ }^{23}$ He was the one responsible for the administration of a province during the Ottoman State.

${ }^{24}$ It is also called "Ahi-order or ahi community".
} 
Unit 5 is a World Power Ottoman (1453-1595). The first topic of the unit is the Conquest of Istanbul. Here, the issues of conquest, causes, and consequences of conquest are discussed. Concepts of conquest, taking possession of a place, and occupation have different meanings in literature. These concepts are also sociological concepts because they result in significant social changes. For this reason, when this subject was examined in the book, it had been stated that the Orthodox people were given freedom of religion and conscience as a result of the conquest, that marriage, divorce and funeral and burial works would be carried out according to their traditions, that it was assured by the state that the churches would be protected and the rights of the Orthodox people would be guaranteed. Also, the Patriarchate institution continued. At the same time, in this period, the borders of the country expanded with conquests, and the people from many religions and nations were included within the borders of the empire. This played an important role in the administrative, cultural, and demographic institutionalization of the Ottoman State in all aspects. In this period, the Ottoman State dominated not only non-Muslim countries but also Islamic geography. Accordingly, this had political, religious, and social impacts, and especially the handover of the caliphate had important consequences in terms of the leadership struggle in the Islamic world. The second topic of the unit is that the Ottoman State took the upper hand also in the seas in this period, that it took control of the trade routes, that it was what economic policies were followed in this period, that it was what concessions were given to Venice and France and as a result of this, what developments (Geographical Discoveries, its causes, and consequences, Renaissance, Reform) happened in Europe. Every social phenomenon is a historical phenomenon and every historical phenomenon is a social phenomenon (Ergun, 1973, p. 21). For example, some developments in Europe in the $15^{\text {th }}$ century were the result of political, social, economic, and religious developments in Europe since the immigration of tribes. These developments covering a period of nearly a thousand years resulted as a social need and explosion. The fact that these social classes which had been oppressed for hundreds of years under the pressure of feudalism caused geographical discoveries with the addition of political and religious reasons, especially economic ones. As a result of these, finding new riches besides gold and silver from the new continent caused economic strengthening through trade, and also this led to advances in science and art. Thus, the Renaissance first started in Italy and then spread to other countries in Europe. This situation eliminated the scholastic thought, and then the Reform started in places where there was religious oppression felt in almost every part of Europe in the process. New religious sects emerged. All this brought about a major social change and its effects were seen almost anywhere in the world. New sects emerging as a result of the reform and cultural changes resulting from this caused sectarian wars that would last for many years in Europe. Benefiting from this, Suleiman the Magnificent moved more comfortably across Europe and went up to Vienna. All these were related events and developments. In the long term, these developments led to the French Revolution, the Industrial Revolution, colonialism, and important social changes in this direction.

In explaining all these social changes and developments, the sociological perspective is extremely important to ensure permanent learning without relying on memorization. Understanding and comprehending today's European society, its institutions, and political developments are important in this sense. Likewise, the sociological approach will make a significant contribution to learn the changes and the effects of these developments in the Ottoman State, its politics and society by the students, and to provide them with more permanent learning.

Unit 6 is Sultan and Ottoman Central Organization. In the Turkish state organization, the Sultan and his mission was important. State lands in the Ottoman Empire belonged to the Sultan. The Sultan would allow his brothers to be killed if it was necessary for the continuity of the state. The last word in the state administration belonged to him. Everything that he said within the framework of customary law and Islamic law was considered as law. The confiscation system which had been applied since its foundation, namely the transfer of a large part of his goods to the state treasury when the statesman died, prevented the formation of the feudal system and strengthened the state authority. 
Topkapı palace was not only the residence of the Sultan and his family, but also was an institution where relations between the Sultan and the people were established, where some of the state officials worked, where meetings with foreign state representatives were held, and where some political and administrative ceremonies were held. Topkapı palace consisted of three sections: Harem, Enderun, and Birun. The status and duties of people living or working in these three sections were also different (Yediyıldız, 2002, p. 345). Everyone in the palace lived according to the protocol rules. Holy relics were kept in the Harem. Harem was a kind of school where the palace women learned a language, literature, music, and Ottoman culture. Divan meetings were held in the place called Kubbealtı in Topkapı Palace. The decisions taken in the divan were considered as law. There was no inheritance system bound by certain rules. The eldest son was heir to the throne, but all men from the ruler family had the right to ascend the throne. This led to the issue of killing brothers.

In this unit, there are such questions as "What is the importance of the palace for the state organization and society? What kind of mission does the society impose on the palace? Why is the palace sacred in the eyes of people? What role does this have in the continuity of the state? What are the factors strengthening the state authority in the Ottoman? What are the factors causing the brother to be killed? What is the confiscation system? Why is it implemented? What are the duties of the Sultan against the people in Ottoman politics? What are the consequences of the Sultan's failure to fulfil them? Why is the education of Shahzades ${ }^{25}$ important? What is the sanjak system? What role does it have in the continuity of the state?" Getting the perspective of sociology addressing all these questions in terms of state organization and social peace by students will be more effective in terms of teaching and learning history. Also, many concepts and expressions related to institutions and organizations in the unit, and their functioning are concepts and institutions in sociology. Their meaning and functioning in the continuity of the state and society are one of the most important areas of sociology today. If these are associated with historical events and are explained with examples, they will provide effective learning for students.

Unit 7 is Ottoman Social Order in the Classical Age. In this unit, the Ottoman social order, and the systems and elements in this order are mentioned. Firstly, the "nation system" which emerged as a result of the fact that people from many races, religions, and sects were included within the borders of the country with the expansion of the country's borders during the reign of Fatih Sultan Mehmet (1432-1481) and which was specific to the Ottoman State is mentioned. The nation system was the organization of all the people creating the Ottoman society based on religion or sect based on some principles of Islamic law rather than on the basis of race. Every faith community was released in itself (Yediyıldız, 2002, p. 341-342). It was based on the idea of tolerance and coexistence. Everyone accepting Islam without racial discrimination was called the Muslim Nation. Christians and Jews are mentioned as the People of the Book. According to Islamic law, they were given freedom of religion and worship and also were guaranteed security of life and property. Apart from these, there were groups such as Majūses, Zoroastrians, and pagans. The most crowded group within the Ottoman nation system was the Orthodox nation. Its religious and administrative centers were the Fener Patriarchate. This patriarchate was also called the Greek Patriarchate since the Orthodox majority were Greek. Another Christian nation having a separate status within the Ottoman society was the Armenians. Armenians from Yerevan were subject to Eçmiyadzin Cathogicos (chief patriarchate), Armenians from Van - to Akdamar Cathogicos, Armenians from Kozan, and Maraş and Aleppo - to Sis Cathogicos. Georgian and Syriac communities were keeping their characteristics; their leaders had authority over their communities. Among Jews, unlike Christians, ethnicity, religion, and community were overlapping with each other. The divisions under the names of Romaniotes, Ashkenazim, Sephardim, and Karaism were not due to ethnicity or religious understanding, but the cultural effects of the regions where they lived (Ortaylı, 2002, p. 392-393; Yediyıldız, 2002, p. 343-344; Ercan, 1999, p. 198-199). In short, the word "nation" in the Ottoman State was used for religious communities whose legal statues

${ }^{25}$ Sultan's son was called "Shahzade". 
were determined. Again in this unit, the fact that urban and rural cultures have an important place in Ottoman social life, should be mentioned. Information about life, neighbourhood structures, and places of worship, bazaar, and shopping districts in the cities were provided. The importance of these in social life and their roles in strengthening social ties are mentioned. The sense of entertainment, culture, weddings, fairs, and religious ceremonies are emphasized. These were important events for people to socialize. Information about Ottoman cuisine and food culture was also provided. Moreover, clothing culture formed by the effects of such elements as religious rules, environment, social structure, tradition, and laws is another topic in this unit. It was possible to understand the status of the person in the society and his nationality from the shape, colour, and material of the clothing that he wore. Another subject of the unit is the soil system and its features in the Ottoman State. In the formation of this system, the soil system applied in the previous Turkish-Islamic states was taken as a sample, and the same time, the soil systems applied in civilizations such as Rome, Eastern Rome, and Iran were also used concerning the use of soil in this wide geography. According to its ownership, the soil was divided into three parts, and they were also divided into parts in themselves according to the use of the land. The foundation land and the foundation system which came from Islam were extremely important in terms of ensuring solidarity in the Ottoman community system. This system was very effective in the social, economic, and cultural life of Islamic countries. It played an important role in the protection of social peace and justice and the positive development of the relations among the state, society, and the individual. Besides, the guild organization, vocational training, and professional groups are given extensive space in the unit.

There are such questions as "What is the national system, and what are its features in terms of sociology? Are they reflected in the Turkish state and society today?" For example, the concept of race comes to mind when the nation is mentioned in Europe. When the Ottoman Empire collapsed and instead when the Republic of Turkey, a new government, was established, and the principle of nationalism was also one of the basic principles, the phrase 'the Turkish nation' was used to refer to all peoples living within the borders of Turkey. The concept of the minority was used for non-Muslim people within the borders of Turkey. There are also such questions as "Could this understanding serve as an example for the national system? What is the Islamic culture? What kind of changes did the physical structures of the conquered cities have? What are the features of urban culture? What were the common places used by the people of the city, and what was their importance in social life? What cultures have an impact on today's Turkish culture and community life? What cuisines have effects on today's Turkish cuisine? Why does folkloric clothing differ from region to region? What can be said when the peasant in the Ottoman land system and the peasant in the European feudal system are compared? What is the Asian production style? What are the contributions of the foundation system to public peace?" Many questions such as these and the answers to be given to them are important in explaining today's social events and lives, and, additionally, explaining sociologically the examples and the concepts that will be given from today to these subjects in history lessons will provide effective learning.

Today, an interdisciplinary approach is becoming more and more effective in many fields. Therefore, the curricula are now prepared based on this approach. It is possible to benefit from many disciplines in teaching history topics. According to the features of the topics, benefiting from different disciplines is extremely important for the realization and permanence of learning. On teaching / learning the concepts and subjects in history lessons, when the relation between history and sociology is examined within the context of the $10^{\text {th }}$-grade history course, the curriculum and $10^{\text {th }}$-grade history coursebook should be prepared in line with this program. It has been shown in the article that history and sociology issues intersect at many points. History will help sociology in explaining and understanding the behaviour of society in the historical process, and also the fact that many examples of these developments in history continue today make important contributions to sociology, which makes the course of history more tangible and understandable. When $10^{\text {th }}$-grade history course curriculum and $10^{\text {th }}$-grade history coursebook prepared in this direction were examined, it was determined that many concepts and phenomena used in sociology are included in the 
statements in the program, and in almost every page of the coursebook. It is a fact that making events concrete to learn historical concepts and topics by the students, and, accordingly, exemplifying them with some of today's events will provide more permanent learning. History is a continuum. Societies' perception of the state, their army organizations, and their developments in social, economic, religious, artistic and cultural, etc. fields continue their existence to a great extent under the developments and conditions of the age. Again, societies' perception of the state, their army organizations, and their developments in social, economic, religious, artistic and cultural, etc. fields differ from each other. It is a fact that some practices open to interpretation even in monotheistic religions with immutable provisions differ in various societies having accepted the same religion, because traditions, customs, value judgments, and experiences that each society brings from the past are different from each other, and every society has based its monotheistic religion on these values. Therefore, except for those put forward with definitive provisions in religion, some rituals show differences from society to society, because each society interprets the parts of the practices open to interpretation with the influence of their own traditional social life, religious beliefs and values. For example, the implementation of some religious understanding and rituals by pre-Islamic Turks as if they still existed in Islam is a clear indication of this. It is possible to see many such examples in today's social life, institutions, and organizations. Recording migrations, epidemics and their effects on societies, and wars and uprisings in some geographies, all of which occur today and are included in the field of sociology, should be recorded by various technological devices from the voices of the people who have experienced or witnessed them, because they will be important resources in future history research and history learning. It is as in the memories written in history, and in the oral history that arise from the narration of people who have experienced the news or events in the newspaper recently.

There is a natural relationship between the sciences of history and sociology, both of which are in the social sciences, in line with the general and specific objectives of the Turkish National Education System in secondary education institutions, and the learning outcomes desired to be provided to students. It is extremely important to reflect this fact in lessons in secondary schools within the scope of history education. In the examined coursebook, there are features related to sociology not only in the information provided, but also in reading passages, questions, tables, and visuals. Therefore, coordinated teaching of the curriculum, learning outcomes, class levels and class hours in the secondary education to achieve the expected goals and achievements of these two disciplines which are so close, even inseparable from each other (as it has been shown in the literature review and the evaluation of the $10^{\text {th }}$-grade history coursebook) is extremely important for ensuring permanent learning. 


\section{References}

Abrams, P. (1980). History, sociology, historical sociology, Oxford University Press on behalf of Past and Present Society, 87, 3-16.

Akran, S. K. (2019). 1924-2009 tarihleri arasında Atatürkçülük ve Türk kültürü konularının sosyoloji dersindeki yeri. Ege Eğitim Dergisi. 20 (1), 223-243.

Aksoy, M. (1998). Sosyoloji ve tarih ilişkisi. Türk Dünyası Tarih Dergisi, 134, 22-26.

Aksoy, M. (2000). Sosyal bilimler ve sosyoloji. İstanbul: Alfa Yayınları.

Arslanoğlu, ì. (2001). Ortaöğretimde sosyoloji ders kitapları. Kastamonu Eğitim Dergisi, 9 (1), 67-80.

Arslanoğlu, ì. (2012). Genel sosyoloji. Ankara: Gazi Kitabevi.

Barkan, Ö.L. (1942). Osmanlı İmparatorluğu'nda bir iskân ve kolonizasyon metodu olarak vakıflar ve temlikler I: İstila devirlerinin kolonizatör Türk dervişleri ve zaviyeler. Vakıflar Dergisi, 2, İstanbul, 279-386.

Bulut, Y. (2011). Türkiye'de sosyoloji eğitimi. Sosyoloji Dergisi, 3 (23), 1-18.

Calhoun, C. (1987). History and sociology in Britain: a review article. Comparative Studies in Society and History, 29 (3). pp. 615625.

Cangızbay, K. (2002). Sosyoloji üzerine, In M.Ç. Özdemir (Ed). Sorgulanan Sosyoloji (pp. 31-38). Ankara: Eylül Kitap ve Yayınevi.

Carr, E.H. (2003). Tarih nedir? (M. G. Gürtürk, Trans.) İstanbul: Illetişim Yayınları.

Cicioğlu, H. (1985). Türkiye Cumhuriyetinde ilk ve orta öğretim. Ankara: A.Ü. Eğitim Fakültesi Yayınları.

DeCesare, M. (2005). 95 years of teaching high school sociology. Teaching Sociology, 33 (3), 236-251.

Dilek, D. (2002). Tarih derslerinde öğrenme ve düşünce gelişimi. Ankara: Pegem A Yayınları.

Dündar, Ö. (2019). Tarih olaylarının sosyoloji kavramlarıyla ilişkilendirilerek öğretilmesinin akademik başarı ve kalıılığa etkisi (Unpublished master's thesis). Ondokuz Mayıs Üniversitesi Eğitim Bilimleri Enstitüsü. Samsun.

Ekici, E. (2017). Ortaöğretim Sosyoloji Ders Kitabı, Ankara: ADA Matbaacılık.

Erbaş, H. (2017). Sosyolojinin tarih araştırmalarındaki yeri ve önemi: sosyoloji ile tarihi buluşturan damarlar, In E. Baş \& H. Aslan (Eds), Disiplinlerarası ve Tematik Islâm Tarihi Yazıları I, (pp. 258-256). Ankara: Grafiker Yayınları.

Ercan, Y. (1999). Osmanlı Devleti'nde Müslüman olmayan topluluklar (Millet Sistemi). In G. Eren, K. Çiçek \& C. Oğuz (Eds). Osmanı Ansiklopedisi, 4 (pp.197-207). Ankara: Yeni Türkiye Yayınları.

Ergun, D. (1973). Sosyoloji ve tarih. İstanbul: Yar Yayınları.

Fildiş, B. (2015). Braudel'i tarihsel sosyoloji bağlamında okumak. Uluslararası Sosyal Araştırmalar Dergisi, 8 (41), 789-794.

Giddens, A. (2000). Sosyoloji. (H. Özel-C. Güzel, Trans.). Ankara: Ayraç Yayınevi.

Gökçe, B. (2000). Türkiye'de sosyolojinin gelişimi ve örgütlenme süreci. Sosyoloji Araştırmaları Dergisi. Cilt: 3, Sayı:1-2, Ankara, 7482.

Hız, K. \& Durdu, Z. (2004). Türkiye'de sosyolojinin kimliği, Sosyoloji Dergisi, 12 (13), 1-14. 
İbn Haldun. (1997). Mukaddime I (Z.K. Ugan, Trans), İstanbul: Milli Eğitim Basımevi.

Kodaman, B. (1997). Tarih araştırmalarında metod meselesi. Akademik Açı, 4, 1-8.

Kösemihal, N.Ş. (1954). Gurvitch sosyolojisi. İstanbul Üniversitesi Sosyoloji Dergisi, 2, (9), 141-163.

Kürkçüoğlu, E. (2013). Anadolu'nun parlayan yüzü; Kayılar. Atatürk Üniversitesi, Sosyal Bilimler Dergisi, 51, 135-148.

Kütükoğlu, M. S. (1990). Tarih araştırmalarında usul. İstanbul: İstanbul Üniversitesi Edebiyat Fakültesi Yayınları.

Mäki, U. (2016). Philosophy of interdisciplinarity. What? Why? How? European Journal for Philosophy of Science. 6, 327-342.

Meriç, Ü. (2012). Türkiye kanatlarınızın altında. İstanbul: Timaş Yayınları.

Mills, C.W. (1959). The Sociological Imagination. New York: Oxford University Press.

Ortaylı, İ. (2002). Osmanlı İmparatorluğu'nda millet sistemi. In H. C. Güzel, K. Çiçek \& S. Koca (Eds), Türkler Ansiklopedisi, 10 (pp. 393- 399), Ankara: Yeni Türkiye Yayınları.

Özçelik, İ. (2001). Tarih araştırmalarında yöntem ve teknikler. Ankara: Gündüz Eğitim ve Yayıncılık.

Ögel, B. (2016). Türklerde devlet anlayışı: 13. yüzyıl sonlarına kadar. İstanbul: Ötüken Neşriyat.

Sezer, B. (1993). Sosyolojide yöntem tartışmaları. İstanbul: Sümer Kitabevi Yayınları.

Skocpol, T. (1979). States and Social Revolutions. Amcomparative Analysis of France, Russia, and China. London, New York, Melbourne: Cambridge University Press.

Skocpol, T. (1999). Tarihsel sosyoloji. (A. Fethi, Trans). İstanbul: Tarih Vakfı Yurt Yayınları.

Subaşı, N. (2000). "Kutsal tarih"in dinî sosyolojisi. Yüzüncü Yıl Üniversitesi Ilahiyat Fakültesi Dergisi, 3, 63-83.

Şimşirgil, A. (2013). Osmanlı'da iskân ve göç. Eskişehir: Anadolu Üniversitesi.

Togan, Z.V. (1985). Tarihte usûl. İstanbul: Enderun Kitapevi.

Uzunçarşılı, İ.H. (1988). Osmanlı Devlet Teşkilatında Kapıkulu Ocakları. Ankara: Türk Tarih Kurumu Basımevi.

Ünal, F. \& Ünal, M. (2010). Türkiye'de ortaöğrenim programlarının gelişimi. Sosyal Bilimler Araştırmaları Dergisi. I, 110-125.

Ünlü, M. (2010). Tanzimat Sonrasında Balkanlardan Karadeniz'e Sürgünler. History Studies, 2 (2), 305-320.

Yediyıldız, B. (2002). Klasik Dönem Osmanlı Toplumuna Genel Bir Bakış. In H. C. Güzel, K. Çiçek \& S. Koca (Eds), Türkler Ansiklopedisi, 10 (pp. 330- 392), Ankara: Yeni Türkiye Yayınları.

Yalansız, N. (2009). Karşılaştırmalı tarih: Tarih öğretiminde yeni bir yaklaşım. Uluslararası Sosyal Araştırmalar Dergisi. 2 (9), $493-$ 498.

Yeğen, C. (2016). Annales okulu, Marc Bloch ve "tarih savunusu: veya tarihçilik mesleği" yapıtı üzerinden Bloch'un tarih anlayışı. Abant Kültürel Araştırmalar Dergisi (AKAR), 1(1), 25-29.

Yıldııım, A. \& Şimşek, H. (2005). Sosyal bilimlerde nitel araştırma yöntemleri. Ankara: Seçkin Yayınları.

Yüksel, E., Kapar, M. A., Bildik, F., Şahin, K., Şafak, L., Ardıç, M., Bağcı, Ö., Yıldız, S. (2019). Ortaöğretim tarih 10 ders kitabı, Ankara: Milli Eğitim Bakanlığı yayınları. 